\title{
TEACHER'S RESPONSIBILITY IN ISLAMIC EDUCATION (RELEVANCE OF HAMKA AND HASAN LANGGULUNG THOUGHT)
}

\author{
Nurhadi \& Muhammad Irhamuddin Harahap \\ STAI Al-Azhar Pekanbaru ; UIN Suska Riau \\ alhadijurnal@gmail.com
}

\begin{abstract}
Duties and responsibilities of teachers are not limited in society, even teachers included in this case are essentially strategic components that have an important role and responsibility in determining the progress of the nation's life and become the foundation of expectations of children's parents to make their children good children (anaks haleb) who know how to carry out their religious obligations and have a noble character (akblak al-karimah). This study aims to determine; What are the Responsibilities of Teachers in Islamic Education according to Hasan Langgulung's Thought?. What are the Responsibilities of Teachers in Islamic Education according to Buya Hamka's Thought?. What is the relevance of Hasan Langgulung and Buya Hamka's thoughts on the Responsibilities of Teachers in Islamic Education?. This research is a library research that uses various sources of literature as a source of research data. Primary data sources are the book Hamka Institution of Life and Budi and Hasan Langgulung Man and Education, An Analysis of Psychology, Philosophy and Education. While secondary data sources in research are books, articles, magazines, newspapers, or other sources, which are then drawn from these data. Based on the results of the processed data, it can be seen that the responsibilities of Teachers in Islamic Education according to Buya Hamka's thinking based on the explanation above, then the responsibility of educators namely educating: a). Faith Education; b). Moral education (morals); c). Physical education (physical and spiritual); d). Community social education; e). Intellectual education. While the Responsibility of Teachers in Islamic Education according to Hasan Langgulung's Thought covers at least 7 things, namely: a). Religious education which includes religious education, aqeedah and worship; b). Moral education (morals); c). Physical education which includes physical education and health; d). Psychological education consisting of psychiatric education and feelings; e). Community social education; f). Intellectual education. The relevance of the thoughts of Buya Hamka and Hasan Langgulung about the Responsibilities of Teachers in Islamic Education can be seen that Education basically revolves around science, charity, morals, and justice. All three are concepts that must be interconnected in the education process. Education for humans is not only to fulfill internal interests as dynamic creatures, but also external interests, namely the orderly and harmonious organization of human civilization.
\end{abstract}

Keywords: Responsibility, Teachers, Education, Islam 


\section{INTRODUCTION}

The Messenger of Allah had said in his hadth that happiness will only be achieved for those who have knowledge. The language of science now means to be educated. Through this education humans will easily live in this world. The glory of people who are educated until Allah says they will elevate the people of knowledge and faith. Meaning with this message the expression of Indonesian education leaders namely KI Hajar Dewantara, expressed by Abuddin Nata in his book: "Education is a process carried out with full of awareness aimed at the safety and happiness of human beings and to promote life so as to enhance the degree of humanity".

Abuddin Nata, Philosophy of Islamic Education, Modern Era and contemporary education is currently experiencing a very shallow ebb tide, which is shallow from good values and morals, this is seen from the reality that many children are now trapped in the abyss of mak \siat, even though they are all educated, understand and know the risks of disobedience and crime. On the other hand there are achievements of this nation's children in the international arena, behind it all turned out to be intellectually incapable of maintaining personal morality. This resulted in a crisis of moral character in the world of education, so that Indonesia was unable to withstand the rapid decline in the morals of children in the world of education, from the lowest levels to the highest strata even though morality and morals did not reflect the good. ${ }^{2}$

Educating children is a heavy responsibility. The Messenger of Allah has correctly stated that responsibility as a leader, as a leader must be careful of what he leads. Parents must constantly supervise and pay attention so that they are sure that their children do not get lost and fall. A person cannot be allowed to grow and develop without anyone caring for and guiding, because children can grow wild out of control. Education is the responsibility and obligation of parents because children as the mandate of God Almighty. Therefore, parents should not neglect the needs of children namely love, protection, education and so on.

All that will not be obtained perfectly except in the teachings of Islam, because it comes from the revelation of Allah who best understands the nature of humans as

${ }^{1}$ Abuddin Nata, Filsafat Pendidikan Islam, (Jakarta: Gaya Media Pratama, 2005), hlm.10

2 Abuddin Nata, Filsafat Pendidikan Islam, hlm. 11 
creatures created by Allah. In the hadith narrated by Ibn Majah that the Messenger of Allah said:

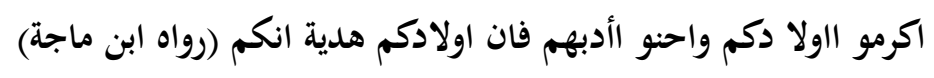

It means: "Honor your children and pay attention to their education, for your children are a gift from God to you.”(HR. Ibnu Majah). ${ }^{3}$

From the hadith above implies that education is very important in shaping the character of children. With good education a noble character will be obtained as a strong foundation in preparing a godly and responsible person for all his problems and tasks in life. ${ }^{4}$ In the interests of education, it is necessary to develop a number of values that are important for children to have in the context of Indonesia's development. The values that will be developed for the Indonesian people are adjusted to the crucial problems faced by the Indonesian people. ${ }^{5}$ As the condition of the Indonesian nation which is categorized in a crisis condition, namely multidimensional krisism in every aspect of life, such as free sex among young people who are increasingly unstoppable by the advice and parental education. Another reality is the existence of drug trafficking which is increasingly pervasive among young people such as students. Acts of brawl, beatings, theft, becoming a group of narcotics and gang robberies committed by teenagers. ${ }^{6}$

The figure of the Hamka buya becomes very special because of its important role in Indonesian history. The unique thing is that he is not only known as a scholar, but also a writer, historian, orator, journalist and even politician. In all the roles he played in Indonesian history, he became the main actor. Yusuf Ahmad and Balo Siregar quoted in Hamka's book titled Lembaga Hidup (Life Institute) that a teacher has responsibility as proof of his professionalism by being a pointer for his students, unlocking his wits and expanding his field his effort. In addition, a teacher must be

${ }^{3}$ Al-Khafiz Abi Abdillah Muh Bin Yazid, Sunan Ibnu Majjah, (Beirut : Dar Al-Fikr, t.th), hlm. 248.

${ }^{4}$ Haya Binti Mubarok Al Barik, Eksiklopedi Wanita Muslimah, (Jakarta:Darul Falah, 2006), hlm.

${ }^{5}$ Dharma Kesuma, dkk, Pendidikan Karakter (Kajian Teori dan Praktik di Sekolab), (Bandung : PT. Remaja Rosdakarya, 2012), hlm. 15

${ }^{6}$ Agus Wibowo, Manajemen Pendidikan Karakter di Sekolab: Konsep dan Praktek Implementasi, (Yogyakarta: Pustaka Pelajar, 2013), hlm. 2 
able to be a good example for his students, temperament can be imitated, fathered his students, be a friend where to shed feelings and complain when the thoughts are piled up. Associate with the students with a gentle attitude, but not cornered, hard but merciful, gentle, still free and free, frank and not clandestine, sometimes the attitude is hard, but in the hardness the student feels alone that at that time, it would have been fair if the teacher had been harsh on him, violent once and for all, it meant that the salt was deliciously chili sauce. ${ }^{7}$

Hasan Langgulung has an extensive background in education and psychology. He produced many works in this field. From his work, among others, Human and Education, an analysis of education and psychology, Islamic education philosophy (translation), some thoughts about Islamic education, and others. From some of the works above it can be seen that Hasan Langgulung is a competent and professional person in this field. According to Hasan Langgulung Islamic education can be viewed from two aspects, namely from the point of view of society and from the point of view of individuals. Society views education as cultural inheritance or cultural values both intellectual, skill, and expertise from the previous generation to the current generation so that the community can be preserved for its survival or to maintain its personality. As for the individual education, it means an effort to develop the potentials of individuals who are still hidden to be actualized concretely, so that the results can be enjoyed by individuals and the community. ${ }^{8}$ Hasan Langgulung is not only an Islamic education figure who has a lot of experience in the field of Islamic education, Langgulung is also a contemporary Islamic education thinker who has a distinctive style and nuances with Islamic Education thoughts in the previous era, this is due to Langgulung's background and way of thinking. which seeks to integrate the concepts of education from various disciplines of psychology, philosophy of education and sosilogi.

Hasan Langgulung also explained the duties and responsibilities of teachers as a profession, including in this case the teacher of religious education as a profession,

${ }^{7}$ M. Yusuf Ahmad, Balo Siregar, Guru Profesional Menurut Imam Al-Ghazali dan Buya Hamka, (Jurnal Al-Hikmah: Agama dan Ilmu Pengetahuan, [S.l.]), Vol. 12, No. 1, hlm. 42

${ }^{8}$ Hasan Langgulung, Asas-Asas pendidikan Islam, (Jakarta : Al-Husna Zikra, 2000), hlm. 1 
including educating, teaching and training. Educating means continuing and developing life values. Teaching can be interpreted as an effort to continue and develop science and technology. While training means developing various skills in students. Besides that the teacher also has tasks in the field of humanity. The duties and responsibilities of teachers in the field of humanity emphasize that teachers in schools must be able to make themselves as second parents. With this teacher's assignment in the field of humanity, the teacher is required to be able to attract sympathy so that he becomes the idol of his students. Whatever lesson is given, it should be able to be a driving force for students in learning. ${ }^{10}$

Based on the explanation above, it can be understood that the duties and responsibilities of teachers are not limited to society, even teachers included in this case are essentially strategic components that have important roles and responsibilities in determining the progress of the nation's life and become the foundation of expectations of the child's parents to make their children good children (anakshaleh) who know how to carry out their religious obligations and have noble character (akhlakul karimah).

However, the phenomenon that occurs in the world of education today is that many children lose their self-identity, will have an impact on behavior that seems to lack thought about the risk of actions that always violate the norm, have risks and even endanger their physical and future. One of the behaviors that often occur among students is brawls between students. This behavior aside from not having any positive value, will also be at risk of injury which of course requires a significant amount of treatment costs which will eventually burden the parents. Besides that makes the child will not feel safe because of the revenge that is ignited by the opponent. ${ }^{11}$ In addition, however, what happens in the field obtained from temporary observations is that Islamic religious education teachers have not been able to make effective their performance and responsibilities as a teacher. This can be seen from the symptoms below:

\footnotetext{
${ }^{10}$ Nurhayati, Tantangan Dan Peluang Guru Pendidikan Agama Islam Di Era Globalisasi, (Jurnal Pendidikan Islam Iqra', Vol. 2. 2018), hlm. 17

${ }^{11}$ Daniel Golemon, Emotional Intelligence (terjemahan). (Jakata : PT Gramedia Pustaka Utama, 2000), hlm. 172
} 
1) The teacher lacks understanding of his duties and responsibilities as a teacher, it is seen from his daily behavior both at school and outside of school

2) The teacher does not pay attention to the learning objectives undertaken.

3) Teachers who only teach without giving guidance to students.

4) Teachers who are still not the main task as a teacher of Islamic education. ${ }^{12}$

Based on the description above, researchers tried to study the thoughts of Buya Hamka and Hasan Langgulung as educational leaders in Indonesia. Then the researcher gave the title: "Teacher Responsibility in Islamic Education (Relevance of Hamka and Hasan Langgulung Thought). This study aims to find out the thinker in the field of responsibility of educators (teachers) for students.

\section{RESEARCH METHODOLOGY}

This research was designed in the form of library research which uses various sources of literature as a source of research data. ${ }^{13}$ Qualitative research category research in the form of concept analysis is research that uses library or library data collection methods, through magazines, articles, books, journals and others). ${ }^{14}$

What is taken up with library research at this stage is that the researcher conducts what is called a literature study, which is to study reference books and the results of previous similar studies that have been carried out by others. The aim is to get a theoretical basis for the problem under study. ${ }^{15}$

Because this research is related to the study of literature, then there is an approach used, namely an expressive approach (relating to the author), an objective

${ }^{12}$ Agus Wibowo, Manajemen Pendidikan Karakter di Sekolah: Konsep dan Praktek Implementasi, (Yogyakarta: Pustaka Pelajar, 2013), hlm. 2

${ }^{13}$ Nyoman Kutha Ratna, Teori, Metode, dan Teknik Penelitian Sastra, DariStrukturalisme Hingga Postrukturalisme Wacana Naratif (Yogyakarta: Pustaka Pelajar, 2010), hlm. 39 hlm. 52

${ }^{14}$ Nana Syaodih Sukmadinata, Metode penelitian pendidikan (Jakrta: Remaja Rosdakarya, 2009),

15Jonathan sarwono, Metode penelitian kuantitatif dan kualitatif, (Yogyakrta:Graha ilmu, 2006), hlm. 6 
approach (related to the text), a mimetic approach (related to the universe) and a pragmatic approach (related to the reception of the reader to the text) ${ }^{16}$

Because of its literary nature, the data sources come from primary and secondary, i.e:

1) Primary sources are the main source or core in research documents. So in this study that can be used as primary sources as follows: a). Buya Hamka's book entitled: Institutions of Life; b). The Buya Hamka book entitled: Budi's Institution; c). Hasan's langgulung book, entitled: Man and Education, An Analysis of Psychology, Philosophy and Education; d). Hasan Langgulung's book is titled: Principles of Islamic Education.

2) Secondary sources, also called supporting sources related to research, for example: a). Book entitled: Under the Protection of the Kaaba; b). Book titled: From the Old Treasury; c). The book entitled: Hamka Ethics, Ethical Rational Based Construction, written by Abd. Haris d). Achmadi's book entitled: Islam as a Paradigm of Educational Sciences; e). Al-Amir Najib Khalid's essay, titled: Tarbiyah Rasulullah saw; f). Book written by Ali Fachri, Hamka as Roman Author: A Literary Study; g). Muhammad AlMiqhwar's book, Family Psychology in Islam; h). His book Abdurrahman Aal-Nahlawi, Islamic Education at Home, Schools and Communities, and others.

In connection with the research conducted is the Responsibility of Teachers in Islamic Education: Comparative Study of the thoughts of Hasan Langgulung and Buya Hamka. So in what is desired in this study is qualitative data. Therefore in analyzing the data using the method of content analysis, which is any technique used to draw conclusions through efforts to find the characteristics of the message, and multiplied objectively and systematically. ${ }^{17}$ Namely by comparing the concepts of the two figures then conclusions can be drawn. Because content analysis is part of the

\footnotetext{
${ }^{16}$ Suwardi Endraswara, Metodelogi Penelitian Sastra: Epistemologi, Model, Teori dan Aplikasi, (Yogyakarta: Caps, 2003), hlm. 9

${ }^{17}$ Noeng Muhadjir, Metodologi Penelitian Kualitatif, Tela'ah Positivistik, Rasionalistik. Fenomenologi, Realisme Methophisik, (Yogyakarta, Rakeb Sarasin, 1989), hlm. 49
} 
research method of the document. ${ }^{18}$ The first step taken in collecting this data is to classify literature books in accordance with the problem discussed, then selected in such a way as a basic concept and then systematically arranged into the form of scientific writing. ${ }^{19}$

Researchers took data sources from the results of library research (Library Research). Existing data will be collected, then analyzed by descriptive analysis method. What is meant by the method of analysis is that the data will be analyzed in order to get scientific knowledge with the object of research, so that the problem will be answered in accordance with the object under study. After the next analysis will be reviewed to ensure the results of the analysis and descriptive, so that the analysis and analysis are really systematic and objective.

\section{DISCUSSION}

\section{Hamka's Perspective Teacher Responsibility Theory}

Buya Hamka's attempt to produce concepts in the renewal of Islamic education is not only on the lecture podium, but also in the books of his works. In reality these ideas and concepts have been realized in formal educational institutions, this is the fact that he is an educator in the educational institutions he founded, also in various other educational institutions, such as the Tabligh School in 1931, Munier School, HI | Muahammadiyah, Kulliyatul Muballighin Muhammadiyah, PTAIN, UI Jakarta, UISU, UMI, PUSROH and YPI Al-Azhar. ${ }^{20}$

However, it turns out these thoughts and ideas have not yet been supported by explanatory interpretations that are interpretive, for example what is the ideal curriculum and operational framework in the learning process in the learning space. He did not make an operational theory of education. But just one attempt to criticize a number of Islamic education systems at that time. He only shows a

${ }^{18}$ Lexy J. Moleong, Metode Penelitian Kualitatif, (Bandung: PT. Remaja Rosdakarya, 2000), hlm.

${ }^{19}$ Noeng Muhadjir, Metodologi Penelitian Kualitatif, Tela'ah Positivistik, Rasionalistik. Fenomenologi, Realisme Methophisik, (Yogyakarta, Rakeb Sarasin, 1989), hlm. 49

${ }^{20}$ Samsul Nizar, Memperbincangken Dinamika Intelektual dan Pemikiran Hamkatentang Pendidikan Islam, (Jakarta: Kencana Prenada Media Group, 2008), hlm. 199 
little symbol and science that is suitable in Islamic education. His framework for education is nothing more than philosophical, which can later be interpreted in accordance with the existing situation at the time. This is one of the shortcomings of the strengths of his thinking in his efforts to create a basic building in Islamic education, including as an educator who is indeed the most important aspect in the process of education and Islamic learning. Education is a component of the success of education in achieving its goals. A very vital factor in the education process is the educator, which is a part of the four factors in it, namely students, educational goals, tools and velue. Madrasa which has adequate infrastructure with modern technological sophistication, of course can be jammed if it does not yet have a skilled operator, and vice versa. ${ }^{21}$

If analyzed simply, the existence of educators is certainly far more urgent than educational technology or learning media. UU SISDIKNAS article 1 RI Law No. 20 of 2003, that the Indonesian nation has made a formula relating to education in this country, namely: 1). Religious spiritual power, 2). Control yourself, 3). Personality, 4). Moral al-Karimah, 5). Skills and skills. It means that when implementing education, it is not just for one purpose, for example intelligence, but it must be holistic with other objectives, in order to form the full character of Indonesian manuisa. Even though this is quite important to be applied so that the education process in this country is not miss oriented (business). From this start as an educator has a very urgent role, because of the severity of the mission that must be carried out as an educator. In order to achieve this mission, this task must be the responsibility of educators, but this is the task of all parties, namely parents and the community. In order to be able to educate according to the ideal, surely the educational goals can be achieved efficiently, effectively, the educator must recognize identity or ma'rifatullah and recognize the norms and ethics, so that the educational propesion of the teacher becomes a good person in imitation and in gugu. Self-introduction to students by educators in three ways, namely: 1). Recognize your own abilities and shortcomings, 2). Recognize the nature of students with all the constitutional psychology, needs,

${ }^{21}$ Abdurrachman Assegaf, Kependidikan Islam, Jurnal Pemikiran, Riset, dan Pengembangan Pendidikan Islam, (Vo. I, No. 1) Februari, 1994, hlm. 20-21 
pain and hope. 3). Openness and always look forward so that all potentials and possibilities exist in students, individual educators, parents of participants in the community as well as the surrounding community. ${ }^{22}$

Judging from Buya Hamka's thoughts, as written in one of his works entitled Budi Institutions, teachers who have success in their proportions as educators, if they can educate students as they progress and develop, of course, educators must always hone the ability and competence of educators wherever obtained. Always steadfast in the education, always wanting to go forward in the modern world, too much associating, both with parents of students or fellow educators, by being able to add questions in the world of education. Always make meetings or share meetings with students' parents and young groups, so that they can connect their kinship in the past and in the future. This is proof that educators, namely teachers, will always carry out an effective learning process if there is a relationship with learners in a simple and harmonious way. Also demands for educators to master the knowledge that will be taught, integrity, good personality, all of which can be used in learning and understanding the condition of students' mental, spiritual, intellectual, intellectual and religious beliefs. There are at least four concepts that must be prioritized, namely: 1). Developing the natural potential of learners. 2). Develop teaching is verbalistic. 3). Record all activities of students as a guide in conducting coaching and education to the front. 4). Formulating a conducive situation in developing an education system effectively, also minimizes the factors that can hamper the realization of the objectives of Islamic education. In order for this approach to be realized properly, according to Buya Hamka, an educator is required to explore what the duties and responsibilities of educators are, which are always trying to help students to gain broad knowledge, noble character, mastering more useful skills, good for him or the surrounding community. In order to realize this condition, an educator is demanded to first broaden his experience and scientific insights, be

\footnotetext{
${ }^{22}$ Amang Fathurrohman, Urgensi Peran Pendidik Dalam Upaya Untuk Mencerdaskan Kebidupan Bangsa, Sengonagung, 23 Desember 2007, artikel online di http://mabadik.wordpress.com/2010/07/09/urgensi-peran-pendidik-dalam-upaya-untukmencerdaskan-kehidupan-bangsa/, di akses 13 Desember 2019.
} 
subtle, wise, forgiving, calm in giving teaching, not be bored in giving learning especially learning material that does not understand, also always pay attention to physical conditions or psychic learners. ${ }^{23}$

Buya Hamka's opinion was raised at school to be continued with did $\backslash$ fish at home. There must be a good agreement between parents of students and teachers at school or education providers. By way of mutual visits and hospitality also mutually examine the situation of students. Islamic methods will be simpler and easier to do. If the place of residence of the teacher and the two parents are close together at least both will meet in the mosque in the evening prayer and evening and others. If you are far apart, you will also meet on Friday prayers. A good educational process will be held if there is discussion between the two parties, namely the teacher and the students' parents. Parental wisdom in educating children will greatly assist the teacher in the learning process at school. If education is only left to the teacher, the results may not be perfect. Circumstances, employment, education and situations in the household will be very influential with students. The proverbial expression "rain water falls from the roof of the house". Therefore, do not be surprised if smart and smart parents will descend to their children, on the contrary if parents are stupid and have a lot of temperament it will usually go down to their children, this is where there is a need for teachers to rectify what is not good through school education institutions. ${ }^{24}$

Buya Hamka always thinks of the wisdom, that children who are born from stupid families will be able to become smart and smart children, here the need for educators as teachers to develop good potential in children. So according to Buya Hamka, the good educator must fulfill the requirements as a good educator, as follows:

1) Always be fair and look objectively at the birth of his students.

2) Maintain muruahnya by behaving noble, good-looking, neat, away from all the ignoble horns. This will be a role model for students. 
3) Transferring the knowledge available to him, without being hidden, of course, the knowledge that will be provided is useful and beneficial for him for the surrounding community and his future.

4) Like to maintain the honor of students by giving independence as human beings who have the potential in order to innovate, be creative in opinions so that they can make the natijah that he feels good.

5) Streaming knowledge that is appropriate to the age and level and thinking of students. ${ }^{25}$

Should not make salary as the first reason in teaching students. Buya Hamka said, it is okay if working differently to find a wage as a reminder. However, if the business is merely looking for a salary, then the sense of responsibility for the good and bad jobs is sometimes even breached. If there are people who do just looking for a salary, then it is hard to believe. Like this he did because he wanted wages and salaries not to want good. So usually if the wage has been received then the value of the work will decrease and the quality is less. ${ }^{26}$

Instill courage and character in students' souls and selves. Courage means to dare to declare an act that believes it is true, is not haphazard and will not be ridiculed by others. In analyzing the values of truth in children, educational experts have formulated this, for example from the European and American States, both of whom argue, as follows:

1) Increase exercise lessons so that the body and body are physically healthy.

2) Presenting and aligning the history of brave people in Islamic struggle.

3) Accustomed to speak honestly in words.

4) Do not believe in the story of khurafat.

5) Always enrich the treasury of useful knowledge. ${ }^{27}$

${ }^{25}$ Samsul Nizar, Memperbincangkan Dinamika Intelektual dan Pemikiran, Jakarta: Kencana Prenada Media Group, 2008), hlm. 152

${ }^{26}$ Hamka, Falsafah Hidup, hlm. 172

${ }^{27}$ Hamka, Falsafah Hidup, hlm. 172 
Buya Hamba told about the teacher Muhammad Syafei (late) grur who was famous in Richu Tanam, so that the teacher succeeded in attaching knowledge in the hearts of students, then Buya Hamka told him: "one day came the teacher Mr. Syafei's teacher requested that that day study earth science and economics. . At that time they were in the school yard not in the classroom. At that moment the teacher taught what the students asked while standing upright. Then the teacher tells about how rich and susburnya beloved homeland, which all of them can be harvested by the nation's children who have seriousness. So Gruru asked the students to climb the Senggalang Mountain, then said that there was a very expensive treasury above. Then he was told to hear the thunderous flow of water in the amazing stem of Anai, then draw conclusions from him. At that time all students were stiff and pensive that seemed to stick in the heart of what the teacher explained. So this kind of learning model is far more beneficial for students' souls, compared to sitting in a row on a learning bench. ${ }^{28}$

This model suggests that a knowledge will not be attached to the heart and soul, will not be installed and embedded in someone if not practiced, accustomed and tested. ${ }^{29}$ Concerning educator scera outline Buya Hamka argues that an educator is a figure who must be responsible for preparing and delivering students to have knowledge that is broad and many, has good character and is beneficial to the lives of the students and the community. ${ }^{30}$

When teaching is presented, the teacher positions the smartest and most knowledgeable in everything. While Shiva is just an object that is still stupid, which will become the teacher's party. While education is more strengthened in channeling behavior, moral ethics and thinking style. With it education is only education in educational institutions, only teaching and training, then it will produce irrational, immoral and aggressive. In Indonesia the education system has followed the bank-style antago- nism model of education, namely teaching teachers, students learning, teachers knowing everything, students who are stupid, teachers who think, students are always thought of, teachers speak, students listen,

\footnotetext{
${ }^{28}$ Hamka, Lembaga budi, hlm. 71

${ }^{29}$ Hamka, Falsafah Hidup, (Jakarta:PustakaPanjimas. 1984), hlm. 54

${ }^{30}$ Hamka, Lembaga budi, hlm. 2-3
} 
teachers organize, students are arranged, teachers choose, students force what the teacher's choice, the teacher acts, the students imagine how the actions are in accordance with the teacher, the teacher chooses what to teach, students adjust to it, the teacher confuses the authority of science with its proportions and is contrary to the freedom of students, the subject teacher the object. Thus the feedback process of teaching, which is certainly far different from the education process. ${ }^{31}$

The existence of educators in the world of education is not as a guarantee but only a process of learning. What is gained by students is the knowledge and insights that are real and appear in general, not just from the teacher. The teacher does not make Shiva as an ideological tendency channel from his teacher. Educators only place themselves as a medium between students and society, between humans and nature. Every knowledge that is learned is only a reflection and sweet achievement of the natural world around it. Implementation of styles of education such as banh still exists today, especially in Islamic boarding school educational institutions. This of course has a reason for the pesntraen cottage teaching materials do not speak Indonesian. Also the memorization pattern is still strong, especially regarding law and monotheism. Certainly very different from the existing formal education, using more Indonesian and teaches insight into abilities related to certain disciplines without fear of the burden of sin that he bears. Actually do not want to try to compare between these two educational institutions, but the reality is like that, also it will not be equated. Buya Hamka is one of those who care about the world of education, aware of the situation, and he experienced it in his childhood. The opinion of Andreas Harefa also said that the reality of existing education cannot be leveled between one another. This merely strengthens the function of educators as a medium to develop and consider the mental, character and nature of human beings who have the same potential. Such an educational model can cause the underdeveloped mental and character of students. Students are not just information and insights that must be understood, but attitudes and ethics because social beings must play their role in

${ }^{31}$ Andrias Harefa, Menjadi Manusia Pembelajar, (Jakarta; Harian Kompas, 2000), hlm. 11 
society. In the old days in Buya Hamka, this matter was already conveyed when talking about education. Specifically educators, in general, Buya Hamka have created a concept that educators are responsible for preparing and delivering students to have broad knowledge, good morals, beneficial to their lives and society. $^{32}$

In the formulation of the objectives of education in this country, namely to equip students with cognitive, affective and psychomotor abilities. All three are very important in the order of community, nation and state life. The hope is that the knowledge gained is not just insights and information but is able to be implemented in real life with assignments of responsibility. In the process of learning in school, students are expected to carry out their duties and responsibilities in the community with all their insights and knowledge. Besides mental strengthening and scientific insight of students according to Buya Hamka must be emphasized on the nature of resignation in teaching. This is the philosophy of his life according to what he talked about in many of his books. For example: "God's prophet is always around every human being, in villages, in cities, on mountains, in valleys, on land and seas. But lust will not feel satisfied or do not remember the nikamat around him, he only saw his deficiency. Which is always observed favor in other places and in the hands of others. One time if there is an opportunity to move to that place, he will regret remembering home, that is, on a useless statement day".33

Actually the obligation of educators in general is only to monitor and prepare and deliver students to have a lot of knowledge, have noble character and be useful for their lives and the surrounding community. If education is carried out that case it could be that students can be expected to be able to realize their life goals in a hablum minallah and hablum minannas. For this problem, there are at least three types of institutions that must contribute to carrying out their duties and responsibilities in implementing education, i.e:

${ }^{32}$ Hamka, Lembaga budi, hlm. 2-3

${ }^{33}$ Hamka, Tenggelamnya Kapal Van Der Wijck, (Jakarta: Balai Pustaka. edisi revisi, 2013), hlm. 


\section{a. Formal Educational Institutions}

One of the well-structured and measured educational institutions is the school. The school functions to carry out all the potential that exists in learners to the maximum so that they have the ability to carry out their life functions in the community. Thus educators have an obligation to guide students to be knowledgeable, moral and beneficial to themselves and their communities.

\section{b. Non Formal Education Institutions}

The most extensive educational institutions are the community and very high influence in the learning process and the formation of the personality of students. The community is a supporting institution in the implementation of the practical education process. This is in accordance with his nature as a social creature who can not live without the help of others. Its existence is cooperating with each other. Starting by forming a harmonious community, enforcing asklak, and living according to the values of the teachings of Islam, and being able to create peace in society. This condition of the community is the hallmark of the ideal society for effective and dynamic education. Therefore formulating the education system requires psychological and sociological and approaches that always accommodate and select social value systems and with an educational approach it is able to play a role as agents of change and customary agents of social change. ${ }^{34}$

Therefore, based on the explanation above, the responsibility of educators is to educate education:

1) Educate education about faith

The belief of someone with God should be able to encourage someone to do good and carry out all forms of commands and prohibitions. Basically, the separation between faith and belief in the heart of obedience in carrying out religious teachings cannot happen properly. Faith in the heart and observance of religious teachings are an inseparable unity. As soon as there is faith and trust in the heart, it is certain that the person concerned will always

${ }^{34}$ Hamka, Lembaga Hidup, (Jakarta: Panjimas, 2001), hlm. 250-257; Ramayulis \& Syamsul Nizar, Ensiklopedi Tokoh Pendidikan Islam (Ciputat: Quantum Teaching, 2005), hlm. 268-274. 
carry out the charitable demands of the teachings of the religion he believes. Then faith and charity are like wood and fruit trees. ${ }^{35}$

2) Educate knowledge about moral and moral education

The condition of thoughts, feelings and speech as well as behavior related to good and bad values is a reflection of morals. Morals are explicitly those things that have to do with the process of socialization, without human morals it is impossible to be able to socialize in society. Moral is an absolute value in the life of society as a whole. Moral assessments are only measured by the local cultural traditions. Moral is a change and three ways of saying someone in interacting with the community. If the deeds, speech, and behavior are in accordance with the values in society, then they are called moral and moral people, but on the contrary it is considered to be wrong in cultural customs called immoral people. Moral is a product of cultural and religious customs. Each cultural and religious custom has its own benchmark in evaluating morals and morals according to their customs and culture. Moral can also be interpreted as attitudes, behaviors, actions, behavior done by someone in the community based on experience, understanding, interpretation, conscience $\backslash$ and advice of others, and others. ${ }^{36}$

The conclusion is that moral is defined as moral education, which is a planned effort to change the attitudes, behavior, actions, behavior of students so that they are able to interact with their environment in accordance with the conditions in an area so that it fits according to their customs and culture.

3) Educate physical education and physical funding

Every human being has a physical body that has the need to eat and drink. Because in general humans without food and drink will die. ${ }^{37}$ But there are procedures that must be done in eating and drinking and all of them have guidance according to the sunnah of the Prophet Muhammad PBUH so that the physical etrjaga well, healthy and powerful. As for teaching this problem for example in the following hadith:

\footnotetext{
${ }^{35}$ Hamka, Lembaga hidup, hlm. 251

${ }^{36}$ Hamka, Lembaga hidup, hlm. 253

${ }^{37}$ Hamka, Lembaga hidup, hlm. 254
} 


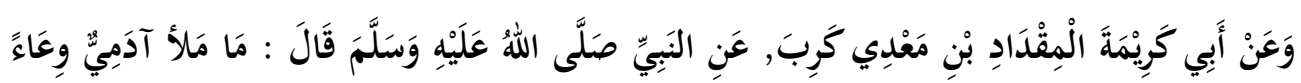

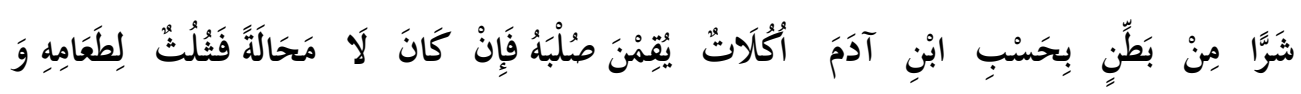

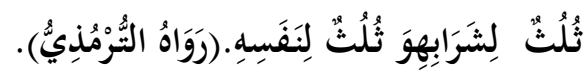

Meaning: "There is nothing worse than a person who crammed his stomach with food. It is enough for someone to eat with a few mouthfuls of food to strengthen his body. If he needs to eat, let his stomach be filled with one third of food, one third of water (drinking), and one third for air (breathing)." (HR. Tirmidzi). ${ }^{38}$

This hadith explains that the fulfillment of excessive physical needs is strictly prohibited. For example, too hungry or too full. The teaching in the hadith above is that humans should eat and drink with one third each to make it ideal and healthy for the body. By doing a diet like the one above will bring balance in a healthy and strong body metabolism. ${ }^{39}$

Provisions in eating and drinking there are some that must be observed and practiced, namely: 1). Large stomach disease nests, gout disease is better than cure. 2). It's not a lot of food that makes the body strong, but eating enough is needed to deliver a strong, healthy and powerful body, so it will be easy to work, act and think according to a balanced brain reason. 3). If you have a lot of stomach, it will be narrower air space. If this happens the metabolism will decrease and give birth to feeling lazy and difficult to move. ${ }^{40}$

If associated with education, the intake of nutrition in food greatly affects the intelligence of students in the use of the learning brain. It is undeniable that nutrition with good nutrition is very closely related to the level of intelligence, growth and mentality of students. ${ }^{41}$

4) Educate the science of community social education

Humans are indeed social beings, so there will be encouragement to interact with each other. The reason is that human beings can also be called

\footnotetext{
${ }^{38}$ Abu Zakariya Yahya An-Nawawi, Riyadhus Sholihin (Semarang : Toha Putra, t.th), hlm. 239 ${ }^{39}$ Hamka, Lembaga hidup, hlm. 255

${ }^{40}$ Ade Hashman, Rahasia Kesehatan Rasulullah, (Jakarta: Noura Books, 2012), hlm. 46.

${ }^{41}$ Hamka, Lembaga hidup, hlm. 255
} 
community, everyone will get to know others by their behavior with others as well. In fact, in socializing human beings, Hraus behaves as follows: 1). Always tolerate. 2). Have high social solidarity. 3). Respect and respect each other. 4). Always helping others. ${ }^{42}$

5) Educate intellectual rational education

The ratio in a large Indonesian dictionary is interpreted as common sense thinking which turns one's mindset into something useful, intelligent, mature and has a high enough scientific knowledge. The ratio is often also referred to as reason, another term is ligika, reason, intelligence and intellect. ${ }^{43}$

a) Definition of reason is anything that is a combination of the ratio of elements and the heart. Because not everything that makes sense can be crushed. This shows that the ratio does not necessarily coincide with the elements of the heart. In Sidi's view, gazalba reason is at first binding or detaining or differentiating, this is stated in his book entitled "Science and Islam". Intellect is the energy that connects between self as a creature and who owns it, God. According to Harun Nasution in his book "Revelation in Isalam" reason is al-hijr that is holding back, al-Aqil is the person who is holding back and curbing lust. Orange aqil means people who can hold their anger when there is a problem and are able to overcome it in accordance with the wisdom of their minds.

b) Defective logic is the result of rational consideration expressed in words, speech in human language.

c) The meaning of reason is the process of thinking that departs from the experience of the human senses to produce concepts or ideas.

d) Understanding intelligence is a mental ability through the process of thinking rationally, directed and facing the environment effectively. The origin of this word from the English language is intelligence or intelligence. The fact is that intelligence is not only observed but must go through a process of real action from manifesting a rational thought process. 
e) Intellectual nature is intelligent, caring or the ability to think about real problems around them or intelligence in using sharp and useful experiences. In English it is called intellectual.

Although logic and ratio are the same the results of thinking aka healthy but have differences. The character of rational is the most striking of the three wives above. Because the ratio has a level relationship or number between two things that are similar. Logic is more complex than reason. Because logic is made with an explanation expressed in language. Reason is only the thought process that starts from the observation of the senses or instincts. Intelligence according to Sperman and Wyan, both say there is an old concept of something power that completes human rationality as true knowledge. ${ }^{44}$

\section{Theory of Teacher Responsibility Perspective Hasan Langgulung}

Education according to Islam is a person who is responsible for the development of students, this is also supported by the opinions of educator theory according to western understanding. ${ }^{45}$ Educators are teachers who teach in the school environment some knowledge, according to what is the goal of every educational institution. Whereas in understanding Hasan Langgulung educator is someone who flows knowledge to students through the teaching and learning process in class. In a study in the United States of America sham uncle that most of the teachers came from low middle class groups such as farmers, micro entrepreneurs, casual daily laborers. Note that the teacher is urbanizing rural people to urban areas.

Educators who are of farmer and laborer backgrounds are certainly considered, because the rural mindset will carry over when teaching in class with students. Similar to educators who are educated in the city or abroad, then generally will always bring culture on campus where he received education. Indeed, with a high education even though it comes from the lower classes will

${ }^{44}$ Hamka, Lembaga bidup, hlm. 256

${ }^{45}$ Ahmad tafsir, Abmad Ilmu Pendidikan dalam Perspektif Islam, (Bandung: Remaja Rosdakarya, 2007), Cet. VII, hlm. 74 
raise its cultural level, even so the value of rural will also carry over, different from those who actually live in the city, then teach in the city to become educators, will always bring the culture of the cities in front of the participants students. But sometimes in high school students sometimes come from high class. When the teacher learning process is the main key that has full power over students, this is where the need for teachers to instill values and norms to their students. The community's view of an educator is a person who gives knowledge to students in class. According to Hasan Langgulung, educators are also called people who have a lot of knowledge or scholars. ${ }^{46}$ It means that people who have more knowledge than their students. The person Allah gave a lot of knowledge. ${ }^{47}$

The teachings of Islam uphold the knowledgeable people. Basically the glory of educators in Islam, if the educator is ignoring his knowledge. The teachings of Islam are very glorious in science, for people who are studying are called prospective educators, while those who teach are gugu. ${ }^{48}$ The teacher has a very high role in school as a mature person, as a teacher and also as an employee. But the highest is as a teacher and educator. With his position as a teacher or gugu, apalgi religious teacher, then it should be able to be a role model and example in the community. Whatever is learned by the teacher is more mualia than what is commonly demanded by others in general. A teacher as a teacher and coach of young people must be an example, both in schools and going outside of school. An educator and teacher must be aware at all times about his position.

The weight of being an educator, wherever its existence will be the spotlight of the community, the slightest thing will be a force that will be imitated by the community, apalgi religious teachers. Also one in determining whether or not education advances is as a factor of teachers and educators. It is the educators who are the main line in shaping the younger generation and quality human resources in the future. ${ }^{49}$ At the time of the learning process educators are very important in the framework of learning to pass down science, technology and

\footnotetext{
${ }^{46}$ Hasan Langgulung, Peralihan Paradigma dalam Pendidikan Islam dan Sains Sosial, (Jakarta: Gaya Media Pratama, 2002), Cet. I, hlm. 45

47Zakiah Daradjat, dkk., Ilmu Pendidikan Islam, (Jakarta: Bumi Aksara, 2006), Cet. VI, hlm. 40

${ }^{48} \mathrm{Ahmad}$ tafsir, Ilmu Pendidikan dalam Perspektif Islam, hlm. 76

${ }^{49}$ Kunandar, Guru Profesional, (Jakarta: Raja Grafindo Persada, 2007), hlm. 40
} 
culture that will have to develop. Hasan Langgulung believes that the role of the educator in order to save the people and civilization from destruction and destruction is only a name such as ancient Egypt. So without an educator whose function is as a cultural transmister that will die. ${ }^{50}$ In fact, the role of religious teachers from day to day is increasingly heavy, due to the rapid development of science and technology. Educators as the biggest component in the world of education are obliged to compensate for the speed of science and technology so that students can be wise in using it.

According to Hasan Langgulung "the teacher in this new paradigm not only acts as a teacher, but as a motivator and facilitator of the learning process."

a) Motivator

According to Wina Sanjaya "in the learning process, motivation is one of the most important aspects. The learning process will succeed if students have motivation in learning. for that, teachers are required to be creative in arousing student learning motivation." $" 52$

b) Fasilitator

Gruru as a facilitator is demanded to have good communication skills with students. Of course this is very urgent, because the clever grammar in communicating will make it easier for students to learn the lesson will easily motivate their students. Suditman in his book "interaction and motivation for teaching and learning" said that gruru as a facilitator and convenience in PBM, for example, giving the atmosphere in PBM with conducive, harmonious, comfortable, lively and PBM interactions will be effective. ${ }^{53}$

Through the information above, it can be taken several points that the grur in the paradigm of Hasan Langgulung is a cultural transmitter as well as a motivator and facilitator for generating and releasing all the potential that exists

\footnotetext{
${ }^{50}$ Hasan Langgulung, Peralihan Paradigma dalam Pendidikan Islam, hlm. 45

${ }^{51}$ Hasan Langgulung, Pendidikan Islam Menghadapi Abad Ke-21 Jakarta: Pustaka Al-Husna, 1988), Cet. I, hlm. 86

${ }^{52}$ Wina sanjaya, Strategi Pembelajaran, (Jakarta: Kencana, 2008), Cet. V, hlm. 28

${ }^{53}$ Sardiman A. M., Interaksi dan Motivasi Belajar Mengajar, (Jakarta: Raja Grafindo Persada, 2003), Cet. X, hlm.144
} 
in students so as to achieve the goal as an educator. For this purpose, Hasan Langgulung requires that educators must possess three kinds of knowledge, namely: 1). General knowledge, namely teaching material that is always associated with religion and the public. 2). Propesiology is the knowledge about the material associated with propesi educators by attending training. 3). Specific knowledge is some special knowledge that must be received by the teacher in accordance with the level of education and learning units at the level taught. ${ }^{54}$

To complete this paper, the author adds about the position and role of teachers from several education experts. As applied by Syafrudin Nurdin that "the teacher's office consists of four activities, namely: (a) Education, (b) Teaching and learning process or counseling, (c) Professional development and (d) Supporting teaching and learning process or guidance and counseling." ${ }^{, 55}$

Zahara Idris said that the role of educators was to guide PBM in achieving educational goals. ${ }^{56}$ Another opinion says that educators as instructors, mentors, leaders of scientists, liaison, modemisators and builders. ${ }^{57}$ Then the meaning will be explained in detail as follows:

a) Educators as instructors, namely as teachers who deliver subject matter to students so as to understand well what is taught by gruru.

b) Educators as mentors, namely providing assistance to students to be able to solve problems, know themselves, and adjust themselves to the surrounding environment.

c) Educators as leaders are able to supervise all students, make lesson plans, make management learn and manage discipline in the classroom.

\footnotetext{
${ }^{54}$ Hasan Langgulung, Manusia dan Pendidikan: Suatu Analisis Psikologi dan Pendidikan, (Jakarta: Al-Husna, 1995), hlm. 233-235 Cet. I, hlm.11

${ }^{55}$ Syafrudin Nurdin, Guru Profesional Dan Implementasi Kurikulum, (Jakarta: Ciputat Perss, 2002),

56Zahara Idris, Dasar-dasar Pendidikan, (Bandung: Angkasa, 1982), Cet. I, hlm. 77

${ }^{57}$ Departemen Agama RI, Wawasan Tugas Guru dan Tenaga Pendidikan, (Jakarta: Dirjen Kelembagaan Agama Islam, 2005), hlm. 72-76
} 
d) Educators as scientists are pious people who know a lot about how students are obliged and are responsible for developing and fostering the knowledge they have.

e) Educators as individuals are people who have the characteristics that must be liked by students, parents and the community.

f) Educators as a liaison for the place to convey and inherit a culture of technology and knowledge. The school is also called a place to gather aspirations, problems, needs, interests, talents, and guidance.

g) Educators as modemisatorm that must always participate in the renewal efforts in the field of science that will be conveyed to the extent that students are able to accept and always instill innovation in order to always hold updates.

h) Educators as builders, they must be able to use all opportunities to help the success of community development.

Responsibility in this context a person's emotional ties come from his physical and psychological responses. Attention is related to the psychological factor (psychological) of humans in general. Attention also relates to a person's interest in objects based on physical growth and psychological development. In this case, the attention of a child will be different from the attention of a teenager, likewise very different from the attention of an adult or parent. In this case, the attention of parents to their children depends on how much emotional ties.

As has been explained above that the teacher's role is also as a motivator and facilitator in addition to being a teacher, that is Hasan Langgulung's opinion about the responsibility of educators, the duties and responsibilities of educators according to him are as follows:

a) The responsibility of the educator as a motivator to all students by focusing on giving direction and motivating so that educational goals are achieved and can be applied.

b) The responsibility of the teacher provides the facilitator for students to be able to achieve educational goals such as expectations. 
c) The responsibilities of the teacher as a helper in the development of all aspects of students' personalities, for example attitudes, values and self-adjustment to the environment around them.

That is the role of the teacher not only as a teacher but as a developer of all personality growth of students. Teachers must also create the best PBM conditions, so that they can stimulate students to learn dynamically to meet educational goals. But the teacher is more than that, which is to help build morals and also nourish faith and piety to God. ${ }^{58}$

Learning in Hasan Langgulung's understanding is the realization of human potential in order to try to compensate for its shortcomings and weaknesses, which is the nature of forgetfulness. Therefore al-Qur'an says that God is the most loyal warning and al-Qur'an gives special warning. According to him also the existing potential is reflected in the 99th Asmaul Husna, if it is re-demonized, the possibility of humanity and society will be fully functional. Conversely, if the potential is not realized, humans will be downloaded from the disease of ignorance, poverty, underdevelopment and starvation which will cause destruction even though they are located on the lake of oil and gold and surrounded by rich natural resources including Islamic countries at this time. ${ }^{59}$

This is also the beginning of the birth of a new theory in education, namely the human reminder who likes to forget or is forgetting. According to custom, humans are forgetful because the potential is not developed and actualized. The existing potential will be buried in him. Therefore it is the responsibility of educators who can develop this potential. then the way the teacher must reduce forgetfulness: ${ }^{60}$ a). It is often desirable for students to be motivated and aware of the learning objectives. b). Shows the poko elements prior to the long and relevant and deep learning material. c). Present the subject matter at the upcoming meeting. d). When asking questions to students, the teacher should pay attention

\footnotetext{
58Zakiah Daradjat, Pendidikan Islam dalam Keluarga dan sekolah, (Jakarta: Ruhama, 1995), Cet. II, hlm. 99

${ }^{59}$ Hasan Langgulung, Peralihan Paradigma dalam Pendidikan Islam, hlm. 48

${ }^{60}$ Tohirin, Psikologi Pembelajaran Pendidikan Agama Islam, Jakarta: Raja Grafindo Persada, 2006), Ed. 1, hlm. 139-140
} 
to the following: 1). Served simply and not stressfully. 2). Short, solid, clear and not confusing. 3). Have one problem. 4). The alternative answer to the question is not just "yes" or "no". 5). Not forcing students who can not answer. 6). Offering questions to other students. 7). Love appreciation if students answer well.

So according to Hasan, the teacher's duty, besides teaching, is also motivating and facilitating the needs of students so that their potential can be developed and actualized and help students live according to the teachings of Islam to become insane kamil. ${ }^{61}$

Hasan Langgulung said that the responsibility of educating a teacher to his students was entirely in his hands, this was not a trivial matter, in fact this had been given the trust from birth to adulthood. If the educator or parents carry out their responsibilities properly and seriously and in accordance with Islamic teachings, God willing will direct their efforts to form students who have personality and privileges. Poko's responsibilities include the education of faith, morals, physical, ratio, psychiatric, social and sex. ${ }^{62}$

According to Hasan Langgulung, teachers have the responsibility to educate and foster all forms of personality that can be done through a variety of ways, both in parental or teacher education with physical and health education, intellectual intellect, psychology, emotions, religion and social morals. ${ }^{63}$

Following the above path, according to Hasan Langgulung, there are 7 things educator responsibility, namely the responsibility of educating with religious education, faith, aqeedah and worship, moral moral education, physical fitness, physical education, psychological education, namely psychology and feelings, social education., also intellectual education and sex. Below is a complete description:

1) The responsibility of educating religious education which includes faith, aqeedah and worship. Although there are two, namely aqidah and worship. Aqidah education is the main task of the family, they are parents from when

\footnotetext{
${ }^{61}$ Hasan Langgulung, Pendidikan Islam Menghadapi, hlm 103

${ }^{62}$ Abdullah Nasih Ulwan, Tarbiyatul Awlad Fil Islam, (Jakarta: Lentera Abadi, 2006), hlm. 157.

${ }^{63}$ Hasan Langgulung, Hasan Langgulung, Manusia dan Pendidikan Suatu Analisis Psikologi, Filsafat dan Pendidikan, (Jakarta: Pustaka Al-Husna, 1994), hlm. 363
} 
they are born. Iamam Gazali emphasized that providing understanding of aqidah children in order to be able to grow and develop with these aqidah. So his efforts by memorizing, understanding, trust and confidence and justify. How to grow confidence by debating and arguing and busiing yourself reading the Qur'an and its interpretation, reading the hadiths and their meanings as well as simple but continuous daily worship duties, so that it becomes habitual. ${ }^{64}$ Worship education by perfecting aqidah, because worship of the fruit of faith or the spirit of worship is aqidah.

2) The responsibility of educating moral and moral education. That is the basic principles and attitudes and character traits that must be accustomed from an early age to adulthood. The way parents work when children have to be done. Because that is the time when children are still clean, respond quickly to teaching. If accustomed from an early age will be accustomed to morality and good morals. ${ }^{65}$

3) Responsibility to educate physical and physical health, that is, so that the students can go through stages of development and growth with a healthy physique that is strong and uplifting until they finally mature. ${ }^{66}$

4) The responsibility of educating with psychological educators, namely psychiatric and feelings, according to Hasan continued the education of children since children begin to understand and dare to be open, capable, helpful and able to withstand anger and love for all good deeds so as to bring it to morals and morals the good one. The purpose of this, in order to shape, foster and balance personality in him. When it is large, it will be easy to carry out all forms of obligations which carry well and perfectly. ${ }^{67}$

5) Responsibility to educate the community's social education is education to always hold fast to the social strata of esthetics and good manners in society, for example friendship and mutual assistance for others. Aiming that children are able and able to socialize and interact with the community well, civilized,

${ }^{64}$ Hasan Langgulung, Manusia dan Pendidikan, hlm. 364

${ }^{65}$ Hasan Langgulung, Hasan Langgulung, Manusia dan Pendidikan, hlm. 366

${ }^{66}$ Abdullah Nasikh Ulwan, Ensiklopedia Pendidikan Akblak Mulia Panduan Mendidik Anak Menurut Islam, (Mesir: Darussalam, 2006), jilid 4, hlm. 1

${ }^{67}$ Hasan Langgulung, Manusia dan Pendidikan, hlm. 369 
and wise in providing solutions to community problems. This is very important for parents as well as educators and teachers so that later if the child is educated with social education it will be easy to live in the community. ${ }^{68}$

6) The responsibility of educating the education of intellectual reasoning is an attempt to shape the students' mindset in order to understand and understand which rights and vanity, so as to bring in new cultures and civilizations. With the maturation of intellectual education, then in the future he will become a knowledgeable oaring, mature in thinking and always responsible for giving birth to culture and civilization. ${ }^{69}$

\section{The Concept of Teacher Responsibility in Perspective of Buya Hamka and} Hasan Langgulung Relevance to Islamic Education

Starting from the explanation above, the responsibility of educators according to the Thought of Buya Hamka and Hasan Langgulung can be seen in the table below:

Table I : Concepts of Teacher Responsibility in Perspective Islamic Education (Buya Hamka and Hasan Langgulung)

\begin{tabular}{|c|l|l|}
\hline \multirow{2}{*}{ No } & \multicolumn{2}{|c|}{ Theory of Teacher Responsibility in Islamic Education } \\
\cline { 2 - 4 } 1 & Buya Hamka & \multicolumn{1}{|c|}{ Hasan Langgulung } \\
\hline 2 & $\begin{array}{l}\text { Education in the Faith } \\
\text { and moral aspects }\end{array}$ & $\begin{array}{l}\text { Religious education which includes } \\
\text { faith, aqeedah and worship }\end{array}$ \\
\hline 3 & $\begin{array}{l}\text { Education on physical (physical) and } \\
\text { spiritual (psychological) aspects }\end{array}$ & $\begin{array}{l}\text { Physical education and health (physical } \\
\text { body and soul) }\end{array}$ \\
\hline 4 & $\begin{array}{l}\text { Education on the social aspects of } \\
\text { society }\end{array}$ & $\begin{array}{l}\text { Heart and conscience education } \\
\text { (psychological) }\end{array}$ \\
\hline 5 & $\begin{array}{l}\text { Education on strengthening } \\
\text { intellectual reasoning ratio } \\
\text { (intellectual) }\end{array}$ & $\begin{array}{l}\text { Education social aspects of the } \\
\text { community }\end{array}$ \\
\hline 6 & \multicolumn{2}{|l}{$\begin{array}{l}\text { Intellectual pedagogic reinforcement } \\
\text { education }\end{array}$} \\
\hline
\end{tabular}

${ }^{68}$ Hasan Langgulung, Manusia dan Pendidikan, hlm. 370

${ }^{69}$ Abdullah Nasikh Ulwan, Tarbiyatul Awlad Fil Islam, jilid 3, hlm. 49 
According to the explanation above the table shows what is the responsibility of educators in Islamic education, is an educational concept that is still relevant and applied in learning in formal and non-formal schools in Indonesia.

Because education is one of the goals to shape and foster and educate humans in achieving the perfection of creation, both physical and spiritual (human beings). Physical education in the context of growing and perfection of strength in the soul and mind. Physical education is also a human nature in the system of science and experience that is always based on religious values and revelation. In guiding human beings in doing good and virtue and devotion to the creator, they also become human beings who have noble character, have good character, have piety, these are the characteristics of every human being. To be clearer and clearer, we will explain one by one as follows:

1) Education in the field of faith and belief. Everyone's belief and faith in God is almighty, while he can motivate himself to always do good according to commands and prohibitions. According to its nature, there is a separation between belief and faith in the hearts of hearts and obedience to their Lord, this should according to Islam not be possible. Faith and obedience are a unity in body and soul. If in the heart of a strong conviction, the deeds will be realized in accordance with the faith he believes, this is like a tree and its fruit, this is faith and charity, commensurate with the second and third verses of Surah al-Ashri: "A person who believes and does good deeds who don't lose in this world" ${ }^{70}$

2) Moral and moral education. Norms and morals are one of the conditions of a state of mind that has feelings which are speech, behavior and behavior that are always associated with good and bad values. Moral means everything that has to do with a person's sodialization process, without human morals it is difficult to socialize his neighbor. Moral is the value of the primacy of life in general community life. Morally assessed with the customs and urf that applies in the community in a place or region. Moral also called actions, behavior, speech, individual people in interacting with each other. If someone does something that is considered in accordance with the urf of a community in an area and agrees for

${ }^{70}$ Hamka, Lembaga hidup, (Jakarta: PT: Pustaka Panjimas, 2001), hlm. 251 
it as a virtue, then it is considered to have good morals, if on the contrary it is considered immoral or bad in character. In the beginning this moral production of culture and religion. Of course every culture has a moral standard that is certainly different from other cultures. Moral is also often referred to by the attitudes, behaviors, actions, behavior that someone does when he is just doing something that suits life experience, understanding, conscience, and the power of science and beliefs, and others. ${ }^{71}$

3) Physical and psychological education (physical and spiritual). Masnusia who have physical and corpse, must have needs, for example eating and drinking. In general, humans without food and drink will perish. ${ }^{72}$ But there are ways that must be understood in eating and drinking, it is merely to maintain the physical body to always be healthy. This has been mentioned by the Apostle PBUH in his hadith as follows:
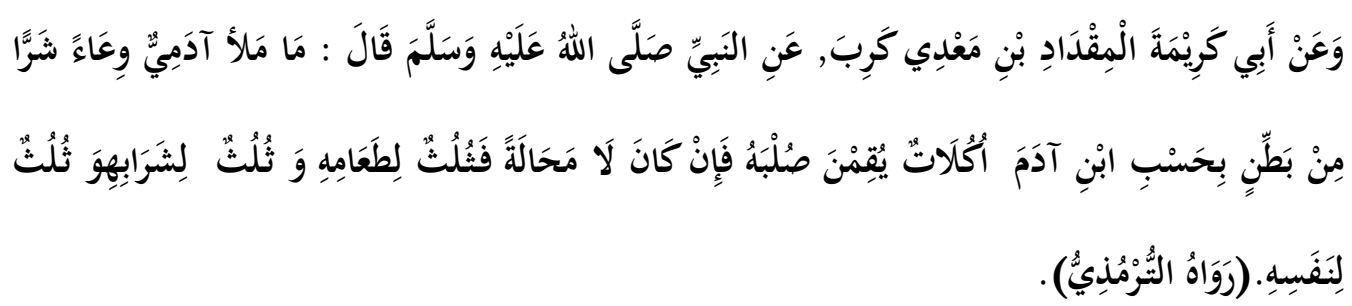

Meaning: "I heard the Apostle peace be upon him saying: the ugliest person is the one who always tightens his stomach. Let someone only provide a few bribes to strengthen his body. If you want to eat, you should fill his stomach with one third each, namely food, drink and air to breathe". (HR. Imam Tirmizi). ${ }^{73}$

The Apostle in the hadith above explained to Muslims that in meeting physical physical needs there is a rule which should be practiced by everyone. The apostle exemplified that in fulfilling the needs of jasmnai it was not too empty so that it brought nausea into angina or was too full so that it was difficult to breathe. Then the Apostle taught which was best for humans, so the Apostle taught that the stomach or stomach is divided into three each, namely one third of food, one

${ }^{71}$ Hamka, Lembaga hidup, hlm. 253
${ }^{72}$ Hamka, Lembaga hidup, hlm. 254
${ }^{73}$ Abu Zakariya Yahya Al-Nawawi, Riyadh al-Shalibin (Semarang : Toha Putra, t.th), hlm. 239 
third of drink and one third of air or grace to breathe. Balance between three out of one third of the stomach will be good and ideal for health and fulfillment of human physical needs. ${ }^{74}$ If related to education, nutritional input from the food a person eats will have an impact on consumption, so the body's metabolism and the way the brain works. Both nutrition and brain intelligence are very closely related to the educational process. So it will impact on intelligence, skill and development skills as well as psychological mental mental growth. ${ }^{75}$

4) Community social science education. It cannot be denied that living humans need other people, this is what is called human social beings. In this case social is often associated with the surrounding community environment. Therefore, humans in social society must know the following: a). tolerance; b). Social solidarity; c). Respect each other and d). Please help each other. ${ }^{76}$

5) Educational intelligence rational mind (intellectual). Rational in the Indonesian language dictionary means thinking that refers to common sense, which one of the material will form the mindset of someone who will lead to something good and useful, has an intelligent mindset, then the mind will be ideal and adequate knowledge. Words commensurate with ratios, such as reason, logic, intellectual reason and intelligence, all of which point to the rational meaning of the mind. ${ }^{77}$

The process of consciously implementing Islamic education in Indonesia is far from the expected results so far. The emergence of new problems and all the problems that have passed have not yet been completed and there is no solution, so that the homework of the authorities and their derivatives in the field of education is still mounting and piling up. Arif Rahman who is an education expert commented that there are several points of weakness in Islamic education in Indonesia, so that progress in the world of education is very slow, namely:

1) Excellence in the cognitive aspect is always the number one in assessing educational success, while the affective and psychomotor aspects are far from the eyes of the eye.

\footnotetext{
${ }^{74}$ Hamka, Lembaga bidup, hlm. 255

${ }^{75}$ Hamka, Lembaga bidup, hlm. 255

${ }^{76}$ Hamka, Lembaga hidup, hlm. 256

${ }^{77}$ Hamka, Lembaga bidup, hlm. 256
} 
2) Always be the object of students even though the students are active actors in education.

3) Always be teaching in education even though it is not like that. Finally, there will be a variety of subject matter in accordance with the facts of reality. Evidently there is a deep gap between the world of education and the world of work.

4) Always be oriented towards titles and titles without any targets to be achieved so that they are more qualified in their knowledge, and carry moral responsibility as educated people, not the other way to pursue titles without common sense.

5) The teacher's proportion is still impressed as a scientific proposition, while the contents of the proposition are like producers and consumers, this worsens when the teacher's salary proportion is still below decent.

6) Current management of education only emphasizes that responsible education is only an educational institution and there are only a few downturns or downturns, very little involving the community, parents of students, teachers and students together.

Educational expert Hasan Langgulung defines education as a process for discovering and developing the abilities and talents inherent in learners. The logic of thought used by Hasan Langgulung means that such education is viewed from three aspects of the community aspect, the individual aspect and the process aspect between individuals and society.

Through the paradigm of the meaning of education above, then the responsibility of family education is at least 7 scopes, namely religious education, in which faith education, aqeedah morals and worship, moral and moral education, physical education namely physical and health education, psychology education \ ologid namely mental and emotional education, social education and intellectual education as well as sex education. The detailed explanation is as follows:

1) Education in religion (aqeedah of faith and worship). In religious education from teachers there are two important things, namely the strengthening of aqidah and worship. Strengthening the main task of aqidah in the family, aqidah must be taught since the child is still early. Imam Gazali said that aqidah of children must 
be dictated from childhood so that children grow and develop above their aqidah, this was quoted by Suwaid in Hasan Langgulung. The first is done by giving memorization related to the Islamic aqeedah (attribute 20), the separation from it (attribute 20) then the belief in that aqeedah. For example, busy children with reading verses and traditions about faith, beliefs and worship as well as their virtues. So that they occupy themselves with daily practices inherent in daily worship. $^{78}$

2) Moral and moral education. Moral and moral education are a series of basic and principles of personality, character and character that must be used to every child from the beginning to understand the good things until they become adults. ${ }^{79}$ Very urgent all efforts related to this matter especially for both parents of children. Because at that time children are still clear and clean, it will be easy to accept and filter what is taught. If this is done early on, children will get used to it in a positive way, it will also have a good impact until adulthood. ${ }^{80}$ So what is meant by moral moral responsibility is to be happy from the basic principle that can be used as a standard of attitudes, character, morals, morals that must be attached to children from an early age, with which they will also develop into mature adults with good morals and perfect. ${ }^{81}$

3) Physical education physical health. The teachings of Islam also save parents and educators to be responsible for physical and physical education. This is done so that children can pass the stages of physical development in their lives to adulthood in the condition of a strong, healthy and energized body. ${ }^{82}$

4) Psychological education. According to Hasan Langgulung, psychiatric education is the education of children from an early age so that children want to understand and dare to be open in attitude, be independent, be helpful, be able to curb

\footnotetext{
${ }^{78}$ Hasan Langgulung, Manusia dan Pendidikan, hlm. 364

${ }^{79}$ Hasan Langgulung, Manusia dan Pendidikan, hlm. 365

${ }^{80}$ Hasan Langgulung, Manusia dan Pendidikan, hlm. 366

${ }^{81}$ Abdullah Nasikh Ulwan, Ensiklopedia Pendidikan Akblak. Mulia Panduan Mendidik Anak. Menurut Islam, (Mesir: Darussalam, 2006), jilid 2, hlm. 71-72; Abdullah Nasih Ulwan, Pendidikan Sosial Anak, (Bandung: Remaja Rosdakarya Offset, 1990), hlm. 2; Abdullah Nasih Ulwan, Tarbiyatul Awlad Fil Islam, (Jakarta: Lentera Abadi, 2006), hlm. 21; Abdullah Nasih Ulwan, Tarbiyatul Aulad fil Islam, terj. Saifullah Kamali dan Hery Noer Ali. Pedoman Pendidikan Anak dalam Islam, (Semarang: asy-syifa', 2001), Jilid II, hlm. 73; Abdullah Nasih Ulwan, Pendidikan Anak dalam Islam, (Jakarta: Pustaka Imani, 2007),

${ }^{82}$ Abdullah Nasikh Ulwan, Ensiklopedia Pendidikan Akblak Mulia, jilid 4, hlm. 1
} hlm. 71 
emotions and are happy in doing good morally and morally. The goal is to shape, foster and balance the child's personality. So that if he grows up he can carry out his obligations which have been imposed on him well and sincerely. ${ }^{83}$

5) Community social education. What is meant by social education is children's education from an early age in adhering to moral ethics in the social community in which the child lives. This will be the basis for good psychology, derived from clean aqeedah, feelings of faith and faith that are very sincere and upright. The goal is for a child to always appear in society as a generation that is able to interact socially with the right, good moral, intelligent minded and wise behavior. This responsibility is one of the urgent issues in order to prepare young people for the continuation of the name of parents. It is even a part of education which includes religious, religious, psychological, and moral education. Because the social education of the community reflects the success of education in the previous stage, so that children are able to carry out their rights and obligations, uphold moral ethics, social criticism of the community, balanced sense of reasoning, socio-political and fairly good interaction with each other. ${ }^{84}$

6) Intellectual reasoning education. Cognitive education is rational education of reason. Aiming in order to form patterns of reasoning of children by teaching all that is useful for children, such as religious knowledge, culture and civilization. Which will remind the child's mind will mature, nuanced science and technology, culture and others. ${ }^{85}$

Observers observation, that the formulation of problems in education in Indonesia that has been conveyed by Arif Rahman above for a long time faced a serious obstacle. This has angered educational thinkers, including Buya Hamka. This is the result of thoughts and reflections that are written or implied in every essay. If Arif Rahman said that education from education now becomes a learning process whose learning material is irrelevant to reality, actually before Arif Rahman, Buya Hamkan has been expressing himself in his various books, especially the issue of Islamic religious education. With that in mind an easy

${ }^{83}$ Hasan Langgulung, Manusia dan Pendidikan, hlm. 369

${ }^{84}$ Hasan Langgulung, Manusia dan Pendidikan, hlm. 370

85 Abdullah Nasikh Ulwan, Ensiklopedia Pendidikan Akblak Mulia, hlm. 49 
generation was born who was good at speaking Arabic like a flowing river but his character was not good. Then this is the impact of schools that do not educate students of religious knowledge. ${ }^{86}$

The statement above has the meaning that learning is not only accompanied by efforts to educate students to produce smart but not good. Such would certainly violate the provisions of the law on the national education system as stipulated in the National Education System Act Article 1 of RI Law No. 20 of 2003.

Those are some things that can be done in order to establish synergy between educators, parents and teachers in the current era. All things and forms of cooperation must be carried out in order to be useful in advancing education in the future. ${ }^{87}$ However, mutual assistance and cooperation will not be perfect without the following two core conditions: 1 ). Should be the direction of parents and teachers do not cross each other. 2). It should help each other and the same work aims at upholding perfection in an effort to foster an Islamic personality. If these two conditions are not neglected, it is very likely that the soul, body, body will be perfect, also balanced so that it will make the people who are impressed with it. ${ }^{88}$

The two collaborations above are one of the efforts to create a generation that is resilient in facing the challenges of living as a person who is competitive and of high quality, so that it will become an emeazing in developing countries such as Indonesia.

Awareness of the importance of synergizing parents, teachers and society is the responsibility of all aspects of Islamic education stakeholders, from the top down to the lowest. This is done so that the educational process is optimal and sustainable, with which students will be controlled from time to time. By practicing this approach, an educational goal will be achieved that does not only educate with imagination. The concept of teacher responsibility according to Hasan Langgulung

${ }^{86}$ Hasbullah, Dasar-Dasar Ilmu Pendidikan; Umum dan Agama Islam, (Jakarta: PT Raja Grafindo Persada, 2005), hlm. 90-94

${ }^{87}$ Hasbullah, Dasar-Dasar Ilmu Pendidikan; hlm. 90-94

${ }^{88}$ Abdullah Nashih Ulwan, Pendidikan Anak Menurut Islam, (Bandung: PT Remaja Rosdakarya, 2012), Cet-1, hlm. 361-362. 
and Buya Hamka is to always consider global values and ethical norms that apply dynamically and develop in society. These norms must be contained in regulations and practices implemented by the entire education system in Indonesia. Buya Hamka's thoughts about teacher responsibility become a visionary educational concept, always paying attention to the future as the future of the Indonesian nation and culture in accordance with human nature that has the same potential. To achieve the goal of comprehensive education, in addition to morale and morals, strengthening competency must also be balanced. The addition of religious knowledge and general science must be the same and strong. Teachers in this case have the responsibility to guide students to achieve it, both in terms of physical and raohani, both the world and the hereafter. Buya Hamka and Hasan langgulung based this in the theory of education so that the Indonesian people could be active and compete in the global world.

Through the explanation of the thoughts of Buya Hamka above, it can be understood that education basically ranges from science, charity and morals to justice. All three are intact concepts, and must be realized in education and learning. Education for humans is not just fulfilling internal interests as dynamic beings, but also external interests, namely the organization of the civilization of the human race as a kaffah and perfect and harmonious.

Using Buya Hamka's thoughts will show its very harmonious relevance between religious and general science. So with them the existence of both is not just recognition of an existing social system, but will control human behavior well. Human behavior will be influenced by the level of education and understanding of knowledge, which should if combined both will protect the nature of himself as a human being, so that humans are born professional in religious and general science. Through this approach the education will play its role as a motivator as well as controlling a good and effective social system.

The current state of education in Indonesia can be indicated to be more oriented towards materiality than to improving individual personality. So Buya Hamka's thoughts about the nature and goals of education that lead to personal empowerment that is able to provide alternative solutions is very relevant to the 
current state of education. Because the problem of education is now too metarialistic, it will be overcome by returning to the personal strengthening of the individual properly and correctly according to his nature.

In order to strengthen personality, educators, students and all those involved in education must integrate religion and general science. It can be one of the efforts to deal with all the problems and challenges of education in Indonesia. Especially Islamic education. Besides that, Buya Hamka's thoughts are still very relevant in this contemporary era to develop optimal personalities in practicing positive thinking to students. Then the concept of the implementation of education according to Buya Hamka has relevance to the dynastic condition as one way to strengthen good personality, including common sense, noble character, ideals and a healthy and healthy physique. Furthermore, the benefits of education according to Buya Hamka are relevant to current conditions, in the context of providing a contemporary national educational paradigm formulation, in order to realize a vision, as well as a balanced goal of Islamic education in the realm of ta'lim, tarbiyah and ta'dib simultaneously and integrated. With high hopes able to reach and give birth to a generation that is able to compete in all fields of community life independently without anyone controlling it from any party.

According to the two views above, that the purpose of education shows the education of a human business process in developing the potential that has been brought from birth naturally, both physically and spiritually to fit the norms of values in society. Basically, the purpose of education has a very noble goal, namely to participate in educating the nation's children and develop all their potentials, so that they become truly human beings who believe in God Almighty God, devote to him, have good morals, be healthy, physically and mentally, able , innovative, creative, independent and become citizens who understand the meaning of democratic are also responsible.

The principles of value education in both views promote the internalization of noble values, develop the development of human nature related to values and norms that are the basis of life, and develop the potential of students, so as to be able to uphold the values of life. The goal to be achieved in education is that students 
have a noble personality, good character and noble character as the goals of national education in Indonesia.

Students, are human beings created by God who have potential and are in a period of growth and development, who need help from educators (adults) to undergo growth and development through its potential.

Efforts in developing all the potential that exists in learners, fostering talent and developing it is a task of education, so that the results of students are able to form the character and character and birth a new civilization in a nation that has dignity in an effort to educate the nation's children, the aim is also to develop potential students to be human beings who always have faith and are devoted to God who is almighty, virtuous, healthy, capable, innovative creative, independent and become citizens who are democratic and responsible. The purpose of education is also to improve the quality of people who have good morals, faith, piety, in order to educate the nation's life. Education is a process of instilling values in students in order to develop the totality of the potential that exists in themselves, both physically and spiritually (physically and mentally).

The existence of noble values embedded in students will make students as God's best creatures. therefore education pays attention to students as humans so that they have a spiritual and intellectual balance, so they are able to develop their potential and are able to instill values in themselves in their lives.

Educators, which means the people who guide the occurrence of the educational process in students, families, schools and communities. Educators have the responsibility for the success of educators, therefore, educators are required to have a personality of morality, because of the noble task of educators. Educators in carrying out tasks and functions are oriented to the dimensions of religious spiritual values, national culture, and responsiveness to the demands and challenges of changing times. From both views, educators have the task of inviting humans to submit to and obey religious rules in order to obtain the salvation of the world and the hereafter. 
Educators are expected to be able to deliver students into human beings who believe and fear God who is almighty, virtuous, healthy, knowledgeable, capable, creative, independent, and become democratic and responsible citizens. The main ability for educators is to have a religious personality, meaning that they are attached to noble values that will be internalized to their students.

These two views state that, as an educator, it is the responsibility of assisting students in introducing values and giving an integrated understanding of the meaning of the whole scope of their lives, also helping students in understanding, giving judgment, making decisions that are appropriate in dealing with various problems in himself, family, community, nation and state, all of whom expect this. The first process that must be done as a student is to be aware of himself as a noble human being, so as to humanize humanity, meaning that human beings must be virtuous, virtuous, always doing good and having the ability to apply their potential and develop good mind and good will in good manner true, both in the family, community, environment, nation and also the country where someone lives and is on this earth of God.

Educational curriculum from both perspectives, includes divine values, and moral values that come from humans. Both of these values are applied in educational subjects to be conveyed to students through the education process, so that it will give birth to students who have spiritual awareness and intellectual awareness.

This effort is carried out because the human soul is naturally able to carry out divine values that are absolute, because God gives human beings the completeness of the soul in the form of potentials to develop the values of life in their individual and social lives. The education curriculum covers the science of knowledge that is beneficial for human advancement and life. The education curriculum from both perspectives shows that in its application and development it refers to the value of religious knowledge and the value of general science, this is the basis for the realization of educational goals.

Basically, the curriculum functions as a tool in achieving the goals of an education, which is to educate the nation's life and develop humanity as a whole, the maximal being a human who always has faith and brtaqwa to God who is almighty 
God and virtuous character, has knowledge and skill skills, healthy born and the mind (physical and spiritual), a straightforward personality and a high sense of social and national responsibility.

The educational environment as a support for the implementation of education and that affects the development of character and personality of children. The function of the educational environment is not as a process of intellectual development and personality of children, but as a process of socialization of children with their environment. Education functions to help develop the potential of students towards maturity.

In the education environment, education plays an important role in shaping the personality of students. To instill value education, educators should be role models and have noble character. The education environment is responsible for implementing education, as well as complementing one another, and forging cooperation between families, schools and communities, in instilling values. The process of investing in value is achieved through the educational process in each of its educational environments. The education environment should be able to organize the morals and ethics of students in their educational environment, to be human beings who are virtuous, responsible, civilized and devoted to God who is almighty.

The education environment should be harmonious in forming, upholding, moral values in harmony with religious values. Because education as a process, which aims to realize the order of human life. The value of devotion to God can be manifested in students, and the behavior of aklakul karimah is internalized in their daily lives.

Therefore, the educational environment is the center of educational activities whose role is to create a servant of God who is a believer and devoted to Allah, has good character, is healthy and affirmative, insightful, knowledgeable, capable, innovative, creative, independent, hard working and becomes a citizen who is a citizen very democratic also very responsible (Chapter II Article 3 UUSPN No. 20 of 2003). 
The essence of the educational environment of the two views is to create, shape and foster human beings to be obedient, to the provisions of their religious teachings, namely to fear God Almighty. Obedience to the provisions of religious teachings and carrying out religious orders, it will deliver humans to achieve safety and happiness in the world and the hereafter.

With an in-depth study of the concept of Islamic education through his writings, Buya Hamka and Hasan Langgulung about the Responsibilities of Teachers in Islamic Education in Learning of the contemporary world according to Buya Hamka's concept of Islamic education is education that is oriented to personal strengthening (reason, reason, ideals and physical form).

\section{CONCLUSION}

A fairly long discussion in this study the author has described in chapter IV discussion and research results, then to conclude as an answer to the formulation of this research problem, the authors will draw the following conclusions:

1) The concept of teacher responsibility in Islamic education according to Buya Hamka's thinking, then according to him the responsibilities of the teacher are as follows:

a) Responsibility in the education of faith aqidah.

b) Responsibility in moral moral education.

c) Physical and spiritual responsibility in physical education.

d) Responsibility in community social education.

e) Responsibility in intellectual rational education.

2) The concept of teacher responsibility in Islamic education in Hasan Langgulung's perspective includes seven things, as follows:

a) Responsibilities in religious education (aqeedah of faith and acts of worship).

b) Responsibility in maral and moral education.

c) Responsibilities in physical education physical health.

d) Responsibilities in psychological education (psychiatric and feelings).

e) Responsibility in community social education. 
f) Responsibility in the education of intellectual reason.

g) Responsibility in Islamic sex education.

3) The concept of teacher responsibility in Islamic education according to the reasoning and philosophy of Buya Hamka and Hasan Langgulung is still very relevant to Islamic education in the contemporary era, the basis of that education includes science, charity, morals and justice. All four are basic concepts that must be interrelated in the education process. Education for humans does not merely fulfill internal interests as dynamic human beings, but also must address the external interests that embody the perfect and harmonious human civilization. With the thoughts of these two figures, if observed it is still very relevant to the current condition, for example the mushrooming of education in kindergarten, kindergarten, elementary school, junior high school and high school with the connection of IT (integrated Islam), which combines religious and general education. The existence of religion is not just just legitimating the existing social system, but needs to see and supervise human behavior well. The behavior of the social system will be more lifelike when the education that is carried out takes into consideration and nurtures the dynamics of the nature of the students while simultaneously integrating the development of religious and general science in a professional way. Through this approach education will be able to play its role as a motivator and controller of an effective and efficient social system.

\section{REFERENCES}

Abdillah Muh Bin Yazid, Al-Khafiz Abi, Sunan Ibnu Majjah, Beirut : Dar Al-Fikr tth AbdulAziz, Syalhub Fuad bin, GurukuMuhammad, Jakarta: Gema Insani Press, 2006 Abdussalam, Suroso, Sistem Pendidikan Islam, Bekasi: Sukses Publisher, 2011

Achmadi, Islam Sebagai Paradigma Ilmu Pendidikan, Yogyakarta: Aditya media, 1992.

Adisusilo, Sutarjo, Pembelajaran Nilai Karakter : Kontruksivisme Dan VCT Sebagai Inovasi Pendekatan Pembelajaran Afektif, Jakarta: PT. Raja Grafindo Persada, 2012

Al Barik, Haya Binti Mubarok, Eksiklopedi Wanita Muslimah, Jakarta:Darul Falah, 2006.

Al-Ainain, AliKhalilAbu, Falsafahal-Tarbiyyabfial-Qur'anal-Karim,T.tp:Daral-Fikral'Araby,1980.

Al-RasyidindanSamsulNizar, FisafatPendidikanIslam, Jakarta:CiputatPress, 2005 
An-Nahlawi, Abdurrahman, Pendidikan Islam Di Rumah, Sekolah dan Masyarakat, Jakarta: Gema Insani, 1995

Arifin, M., Filsafat Pendidikan Islam, Jakarta: Bumi Aksara, 1993

Azmi, Ali, Pemikiran Filsafat Moral Hamka, Tesis Pekanbaru: UIN Susqa Pekanbaru , 2003

Baharuddin ,dkk, Teori Belajar dan Pembelajaran, Yogyakarta: Ar Ruzz Media, 2007

Bahri Djamarah, Syaiful, Guru dan Anak Didik dalam Interaksi Edukatif, Jakarta: Rineka Cipta, 2005.

Burangin, Burhan, "AnalisiData Penelitian Kualitatif Pemahaman Filosofis dan Metodologis ke Arah Penguasaan Model Aplikasi”,Jakarta:RajaGrafindoPesada,2003

D. Marimba, Ahmad, , Pengantar filsafat Pendidikan Islam, Bandung: PT. AL Ma'arif, 1989

Daradjat, Zakiah, Ilmu Pendidikan Islam, Jakarta: Bumi Aksara, 2008

Endraswara, Suwardi, Metodelogi Penelitian Sastra: Epistemologi, Model, Teori dan Aplikasi, Yogyakarta: Caps, 2003

Fachry Ali, Hamka dan Masyarakat Islam Indonesia: Catatan Pendabuluan Riwayat dan Perjuangannya, Prisma, Pebruari, 1983

Hamka Sebagai Pengarang Roman: Sebuah Studi Sastra, Jakarta; Megabokkstore, 1964 Ayahku, Jakarta: Pustaka Panji Mas, 1982

., Kenang-kenangan Hidup, Kuala Lumpur: Pustaka Antara, 1982

H. Hamka, Rusdi, Pribadi dan Martabat Prof. D. Hamka, Jakarta: Pustaka Panjimas, 1983

Hasbullah, Dasar-DasarImuPendidikan;UmumDanAgamaIslam, Jakarta:PTRajaGrafindoPersada, 2005

IbnuRusn, GhazaliTentangPendidikan,Yogyakarta:PustakaPelajar,1998

Abidin,PemikiranAl-

Ismail, Faisal , Paradigma Kebudayaan Islam; Studi Kritis dan Refleksi Historis, Yogyakarta:TitianIlahiPress,1996

Jalaluddin, Psikologi Agama, Jakarta: PT Raja Grafindo Persada , Teologi Pendidikan,Jakarta: PT RajaGrafindoPersada, 2001.

Jamaluddin, Dindin,ParadigmaPendidikanAnakdalamIslam,Bandung:Pustaka Setia, 2013.

Kartono, Kartini, Psikologi Anak, Jakarta: Mandar Maju. 1995

Kesuma, Dharma, dkk, Pendidikan Karakter (Kajian Teori dan Praktik di Sekolab), Bandung : PT. Remaja Rosdakarya, 2012

Kutha Ratna, Nyoman, Teori, Metode, dan Teknik Penelitian Sastra, Dari Strukturalisme Hingga Postrukturalisme Wacana Naratif,Yogyakarta: Pustaka Pelajar, 2010

Langgulung, Hasan, Asas-Asas Pendidikan Islam, Jakarta: Pustaka Al-Husna Baru, 2003, Terbit pertama tahun 1985 
Langgulung, Hasan, Manusia Dan Pendidikan Suatu Anlisa Psikologi Dan Pendidikan Jakarta: Pustaka Al-Husna, 1989, Terbit pertama tahun 1984

M. Moeliono, Anton, et al, Kamus Besar Bahasa Indonesia Jakarta : Balai Pustaka, 1999

M. Yusuf Ahmad, Balo Siregar, Guru Profesional Menurut Imam Al-Ghazali danBuya Hamka, Jurnal Al-Hikmah: Agama dan Ilmu Pengetahuan, [S.l.], v. 12, n. 1

Maunah, Binti, Ilmu Pendidikan, Tulungagung: STAIN Tulungagung, 2001

Moleong, Lexy J., Metode Penelitian Kualitatif, Bandung: PT. Remaja Rosdakarya, 2000

Muhadjir, Noeng, Metodologi Penelitian Kualitatif, Tela'ah Positivistik, Rasionalistik Fenomenologi, Realisme Methophisik, Yogyakarta, Rakeb Sarasin, 1989

Muhaimin,PengembanganKurikulumPendidikan AgamaIslamdiSekolabDasar, Madrasah,danPerguruan Tinggi,Jakarta:RajagrafindoPersada,2010

Mujib, Abdul, Kepribadian dalam Psikologi Islam, Jakarta: PT Raja Grafindo Persada, 2006

Mulyasa, E., Menjadi Guru Profesional, Bandung: Rosda, 2005.

Munardji, Ilmu Pendidikan Islam, Jakarta: PT Bina Ilmu, 2004

Nata, Abuddin,FilsafatPendidikanIslam,Jakarta:GayaMediaPratama,2005

Nizar,Samsul,FilsafatPendidikanIslamPendekatanHistories,TeoritisDanPraktis,Jakarta:Ciput at Pers, 2002

Novan Ardi Wiyani \& Barnawi, Ilmu Pendidikan Islam, Jogjakarta : Ar Ruzz Media 2012

Nurhayati, Tantangan DanPeluang Guru Pendidikan Agama IslamDi EraGlobalisasi, Jurnal Pendidikan Islam Iqra', vol.2. 2018, hlm. 17

Raper, J.H.,FilsafatPolitikPlato,Jakarta:Rajawali,1988

Roesmar, Zainuddin, Tuntunan Dakwah Dalam Masyarakat Pluralistik Persfektif Metode Dakwah Hamka, Pekanbaru: Unri-Press, 2002

Rosyadi, Khoiron,PendidikanProfetik, Yogyakarta: Pustaka Pelajar,2004

Sasono, Adi,SolusiIslam AtasProblematika Umat,Jakarta:GemaInsaniPress,1998

Shalih Baharits, Adnan Hasan, Mendidik Anak Laki-Laki, Jakarta: Gema Insani, 2007

Shihab,M.Quraish,TafsirAl-Misbah:Pesan,KesanDanKeserasianAlQur'an,Jakarta:LenteraHati, 2002, Volume14, Cet-5

Steenbrink, Karel A., Hamka (1980-1981) and the integration of Islamic Ummah of Indonesia, Studika Islamika Indonesian Journal for Islamic Studies, Vo. II Number 3, 1994

Sukardi, Metodologi Penelitian Pendidikan: Kompetensi dan Prakteknya, Cet. Ke-4, Jakarta: Bumi Aksara, 2007.

Sunggono, Bambang,MetodologiPenelitianHukum,Jakarta:PTRajaGrafindo,1997

Suryani, Hadits Tarbawi; Ananlisis Paedagogis Hadits-Hadits Nabi, Yogyakarta: Teras,2012. 136. Lihat juga DEPDIKNAS, Kamus Besar Bahasa Indonesia, Jakarta: BalaiPustaka, 1996. 
Suwarno, Pengantar Umum Pendidikan, Jakarta: Aksara Baru, 1985

Syar'i, Ahmad,Filsafat Pendidikan Islam, Jakarta: PustakaFirdaus,2005.

SyarifH, Ahmad,PendidikanNilaidalamTafsiral-Ažhar, JurnalalHikmahvol.5no.1Maret 2017

Tafsir, Ahmad , Filsafat PendidikanIslami; Integrasi Jasmani, Rohani, dan Kalbu MemanusiakanManusia,Bandung:RemajaRosdakarya,2008

Uhbiyati, Nur,IlmuPendidikanIslam,Bandung:PustakaSetia,1998

Umiarso\&Zamroni,PendidikanPembebasandalamPerspektifBaratdan Timur, Yogyakarta:ArRuzzMedia,2011

Undang-Undang Republik Indonesia Nimor 20 tahun 2003, Tentang Sistem Pendidikan Nasional, Bandung: Citra Umbara, 2006

Undang-UndangRepublikIndonesiaNomor20Tahun2003 TentangSistemPendidikan NasionalPasal1 ayat1

UU RI No. 14 Thn 2005, Tentang Guru dan Dosen, Jakarta: Sinar Grafika, 2014

Wibowo, Agus, Manajemen Pendidikan Karakter di Sekolah: Konsep dan Praktek Implementasi, Yogyakarta: Pustaka Pelajar, 2013

Wijaya, Cece, Kemampuan Guru dalam Proses Belajar Mengajar, Bandung: Remaja Rosdakarya, 1994

Yunus, Mahmud, Pokok-pokok Pendidikan dan Pengajaran, Jakarta: Hida Karya Agung, 1985

Yusuf, Yunan, Corak Pemikiran Kalam Tafsir Al-Az̧ar, Jakarta: Pustaka Panjimas, 1990 